\section{REFERENCES AND NOTES}

1. Behrman, R. E., Lees, M. A., Peterson, E. N., deLannoy, C. W., and Seeds, A. E.: Distribution of the circulation in the normal and asphyxiated fetal primate. Amer. J. Obstet. Gynec., 108: 956 (1970).

2. Buckberg, G. D., Luck, J. C., Payne, D. B., Hoffman, J. I., Archie, J. P., and Fixler, D. E.: Some of the sources of error in measuring regional blood flow with radioactive microspheres. J. Appl. Physiol., 31: 598 (1971).

3. Cockburn, F., Daniel, S. S., Dawes, G. S., James, L. S., Meyers, R. E., Niemann, W., Rodriguez de Curet, H., and Ross, B. B.: The effect of pentobarbital anesthesia on resuscitation and brain damage in fetal rhesus monkeys asphyxiated on delivery. J. Pediat., 75: 281 (1969).

4. Duncan, S. L. B.: The partition of uterine blood flow in the pregnant rabbit. J. Physiol., 204: 421 (1969).

5. Lees, M. H., Bristow, J. D., Way, C., and Brown, M.: Cardiac output by Fick Principle in infants and young children. Amer. $J$. Dis. Child., 114: 144 (1967).

6. Lowry, O. H., Passonneau, J. V., Hasselberger, F. X., and Shulz, D. W.: Effect of ischemia on known substrates and cofactors of the glycolytic pathway in brain. J. Biol. Chem., 239: 18 (1964).

7. Paton, J. B., Fisher, D. E., Saba, T. M., and Behrman, R. E.: Measurement of liver blood flow in the infant monkey. A comparison of methods. Biol. Neonate, 23: 1 (1973).

8. Phibbs, R. H., Wyter, F., and Neutze, J.: Rheology of microspheres injected into circulation of rabbits. Nature, 216:1339 (1967).

Copyright @ 1975 International Pediatric Research Foundation, Inc.
9. Rudolph, A. M, and Heymann, M. A.: The circulation of the fetus in utero. Circ. Res., 21: 163 (1967).

10. Siggaard-Anderson, O.: The $\mathrm{pH} / \mathrm{log} \mathrm{pCO}_{2}$ blood acid-base nomogram revised. Scand. J. Clin. Lab. Invest., 14: 598 (1964).

11. Wechsler, R. L., Dripps, R. D., and Kety, S. S.: Blood flow and oxygen consumption of the human brain during anesthesia produced by thiopental. Anesthesiology, 12: 308 (1951).

12. Hewlett-Packard, Skokie, Ill.

13. Radiometer Division, London Company, Cleveland, Ohio.

14. James G. Biddle Company, Plymouth Meeting, $\mathrm{Pa}$.

15. Minnesota Mining \& Manufacturing Company, Minneapolis, Minn.

16. Technicon Corporation, Tarrytown, N. Y.

17. Model 25601, Nuclear Chicago Corporation, Des Plaines, III.

18. Presented in part at the meeting of the Society for Pediatrics Research, April 30, 1971.

19. The present address of Dr. R. E. Behrman is: Department of Pediatrics, College of Physicians and Surgeons, Columbia University and Babies Hospital, The Children's Medical and Surgical Center of New York, New York, New York.

20. This research was supported in part by DMH Grants nos. 17-344 and 236-12-RD and a grant from the Pharmaceutical Manufacturers Association and the Michael Reese Research Institute. It was performed, in part, while the authors were at the University of Illinois College of Medicine, Chicago, Ill.

21. Requests for reprints should be addressed to: D. E. Fisher, M.D. Department of Pediatrics, Michael Reese Medical Center, 29th St. and Ellis Ave., Chicago, Ill., 60616 (USA).

22. Accepted for publication December 9,1974 .

Pediat. Res. 9: 184-189 (1975)

"Car. factor" deficiency partial thromboplastin time platelets

Printed in U.S.A.

\title{
“Car. Factor” Deficiency Revisited
}

\author{
DIANE M. KOMP(32) \\ University of Virginia School of Medicine, Charlottesville, Virginia, USA
}

\section{Extract}

Three members of a Virginia family with a bleeding disorder were found to have a serum defect in thromboplastin generation similar to the previously reported "Car. factor" deficiency. Sera from three members of the original Car. family did not correct the defect of affected members of the Virginia family. Partial thromboplastin times of Car. deficient individuals and affected members of the Virginia family were normal. Although correction with normal serum is attained in vitro, the serum defect persisted after infusion of fresh frozen plasma.

Platelet function studies of the Virginia family revealed less than $30 \%$ aggregation after the addition of exogenous ADP and disaggregation within $2 \mathrm{~min}$. Evaluation of children with Noonan's syndrome, albinism, and "Portsmouth" syndrome showed coexistent platelet aggregation defects and nonspecific serum defects.

\section{Speculation}

These studies suggest that the Car. factor is nonspecific; the serum defect may result from the interaction of abnormal cellular elements of the blood during clotting of whole blood in glass. This deficiency can be corrected in vitro by the addition of dilute thrombin.
Before the introduction of the partial thromboplastin time (PTT), the thromboplastin generation test (TGT) was used extensively as a screening test for deficiencies of thromboplastin generation. Of the officially recognized plasma coagulation factors, serum defect without plasma defect is produced only by deficiencies of factor IX or X. Various serum defects. have been reported in persons with normal levels of these two factors who do not appear to have inheritable bleeding disorders (2, 9, 15). In 1957, Chirico and McElfresh (8) reported a familial abnormality of thromboplastin generation detected in the serum component of the TGT. This defect was tentatively named "Car. factor" after the Caucasian family of Italian extraction in whom it was detected. The inheritance was most consistent with autosomal dominance; affected family members had moderate to severe bleeding problems.

A Virginia family was found to have a serum defect consistent with the Car. factor deficiency. It is the purpose of this paper to report extended studies that show the nonspecific nature of the Car. factor deficiency.

\section{MATERIALS}

ADP

The sodium salt of ADP trihydrate (25) was dissolved in calcium-free Tyrode's solution to give a concentration of $4 X$ $10^{-5} \mathrm{M}$ 


\section{COLLAGEN}

Calf collagen (25) was homogenized, 2 g collagen in $100 \mathrm{ml}$ Tyrode's solution in a Waring Blendor for $5 \mathrm{~min}$. The homogenate was centrifuged at $800 \times g$ for $15 \mathrm{~min}$. The supernatant was diluted further with Tyrode's solution to the lowest concentration that would still produce maximal aggregation $(1: 40)$.

\section{NOREPINEPHRINE}

L-Norepinephrine bitartrate (26) was dissolved in Tyrode's solution to a concentration of $2 \times 10^{-3} \mathrm{M}$.

\section{THROMBIN}

Bovine thrombin (27) was dissolved in Tyrode's solution to a concentration of $1 \mathrm{unit} / \mathrm{ml}$.

\section{METHODS}

Platelet aggregation studies were performed by a modification of the method of Born and Cross (5) using a Chronolog aggregometer. Patients had not received any medications for a 2 -week period. Blood was anticoagulated with $3.8 \%$ sodium citrate in a ratio of 9 parts whole blood to 1 part anticoagulant in a plastic tube. Platelet-rich plasma (PRP) was obtained by centrifugation at $500 \times \mathrm{g}$ for $15 \mathrm{~min}$ at room temperature. The PRP was adjusted to a platelet count of about $300,000 / \mathrm{mm}^{3}$ by dilution with the subjects' platelet-poor plasma (PPP). Aggregation studies were performed at $37^{\circ}$ with $0.36 \mathrm{ml}$ PRP and $0.04 \mathrm{ml}$ aggregating agent. Platelet adhesiveness to glass was determined by the method of Salzman (24).

Prothrombin time (PT), PTT, platelet counts, fibrinogen level, and factor XIII screen were performed by methods described previously $(6,7,19-21)$. Peripheral smears made directly from finger stick were examined for platelet morphology and clumping. Factors VIII, IX, X, and XII assays were performed by methods based on PT or PTT $(4,10,22$, 23). The PTA and Fletcher factor deficiencies were excluded by assays based on celite-exhausted plasma (13). Prothrombin consumption was tested by the method of Biggs and Macfarlane (4). Bleeding times were performed by a modification of the Ivy method (1). Platelet factor 3 was determined by the method of Hardisty and Hutton (11).

The TGTs were performed by modification of the method of Biggs and Macfarlane (3). Plasma components were prepared by aluminum hydroxide (28) adsorption of citrated plasma. Whole blood was allowed to clot for 1,2 , and $24 \mathrm{hr}$ in contact with the cellular elements in different glass tubes before separation of the sera. Dilutions of plasma and sera were made in imidazole buffer, $\mathrm{pH}$ 7.3, just before use. Recalcification of plasma was performed by the addition of $0.025 \mathrm{ml} 1.0 \mathrm{M} \mathrm{CaCl}_{2}$ and $0.014 \mathrm{ml} 3.8 \%$ inosithin to each milliliter of citrated plasma. Cross-correction studies were performed by the addition of $1 / 5$ volume of diluted correcting serum to $4 / 5$ volume of diluted test serum.

Inhibitor activity was tested by incubation at $37^{\circ}$ of undiluted normal serum with undiluted test serum for up to 1 hr. Aliquots were removed at 15,30 , and $60 \mathrm{~min}$ and diluted to be used immediately in a TGT with normal adsorbed plasma. If an inhibitor were present, a serum defect with increased severity would be produced by progressive incubation.

$\mathrm{BaSO}_{4}$ adsorbed sera were prepared by mixture of $1 \mathrm{ml}$ normal serum with $100 \mathrm{mg} \mathrm{BaSO}$ for $0.5 \mathrm{hr}$. Coumadin serum was obtained by the mixture of sera from five patients who had received doses of Coumadin sufficient to reduce their plasma prothrombin activity to $5 \%$ and give a marked serum defect in the TGT. None of these patients was receiving any other medications. Prothrombin complex concentrate (29) was diluted with physiologic saline to give a factor IX concentra- tion of approximately $1 \mathrm{unit} / \mathrm{ml}$ before further dilution with buffer for use in the TGT.

Studies were performed on six members of two generations of the Virginia family (Fig. 1). Three of the original Car. family (one generation) were restudied in a more limited fashion.

\section{CASE REPORTS}

\section{CASE 1}

$A B$, the propositus, is a 15 -year-old black male who was seen at the University of Virginia Hospital in 1968 for profuse bleeding following a tooth extraction. Transfusion was not necessary but blood loss was sufficient to make him dizzy. Past history included multiple visits to the emergency room for severe nosebleeds. In 1969, after the transfusion of 10 $\mathrm{cc} / \mathrm{kg}$ fresh frozen plasma, the left first permanent molar was extracted and six other teeth were restored under general anesthesia. Bleeding was minimal. In 1973, he suffered avulsion of his right tibial tubercle. The tubercle was pinned without transfusion or bleeding.

On five occasions, including immediately after fresh frozen plasma infusion, TGTs have shown serum defects (Fig. 2). The bleeding time and PTT on those occasions have been normal. Platelet aggregation studies performed on two occasions in 1973 showed absence of secondary wave of aggregation after ADP and disaggregation even with $4 \mu \mathrm{M}$ ADP added.

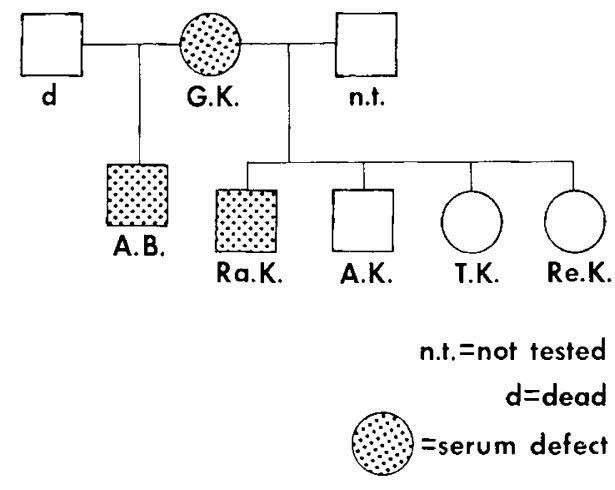

Fig. 1. Virginia family pedigree.
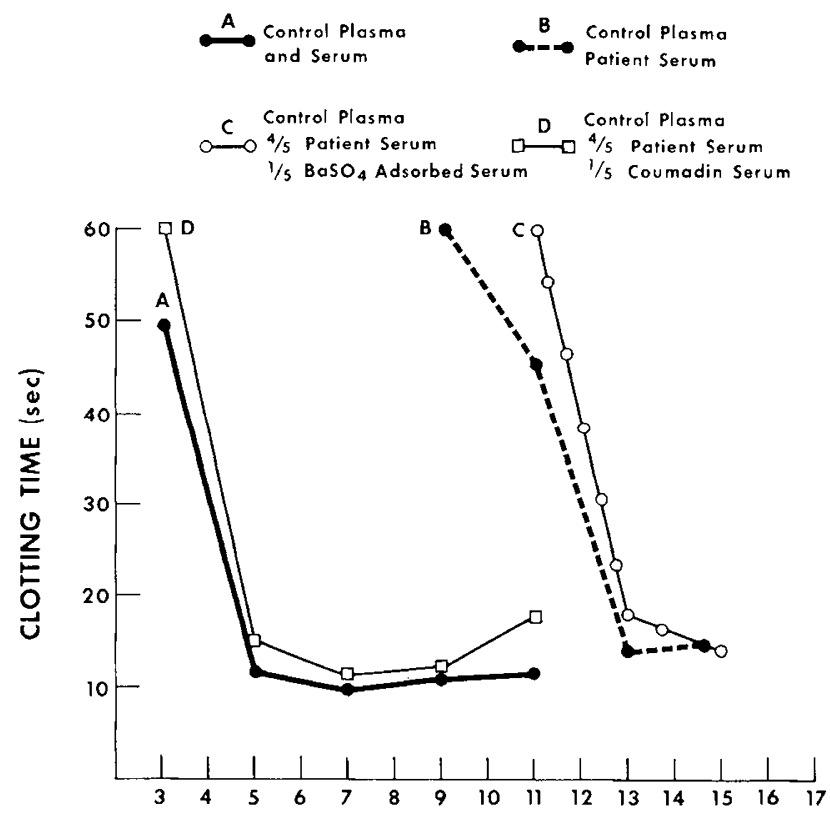

INCUBATION TIME (min)

Fig. 2. Thromboplastin generation tests on patient $A B$ showing influence of normal, adsorbed, and Coumadin serum. 


\section{CASE 2}

$R K$ is a 13-year-old black male who is the half-brother of $A B$. He was circumcised at birth without bleeding. He has a history of frequent severe nosebleeds. In 1969, three teeth were extracted under general anesthesia. No blood product was given and there was no bleeding.

A serum defect was present in the TGT on seven occasions of testing. (Fig. 3). Bleeding time and PTTs have always been normal. Platelet aggregation curves were similar to those obtained in his half-brother (Fig. 4).

\section{CASE 3}

$G K$ is a 35-year-old black woman and the mother of $A B$ and $R K$. She has had multiple episodes of metamenorrhagia but has had six term deliveries and one miscarriage without excessive bleeding. She has had frequent nosebleeds and abnormal hematoma formation after lacerations.

Her coagulation studies have shown normal bleeding time, normal PTT, and a serum defect in the TGT on four occasions. As seen in her sons, platelet aggregation to collagen, norepinephrine, and thrombin was normal. No secondary wave of aggregation was seen after exogenous ADP and rapid disaggregation occurred.

\section{CASES 4, 5, AND 6}

$A K, T K$, and $R e K$ are full siblings of $R K$. They have been completely asymptomatic and show neither abnormal TGT nor platelet aggregation.

\section{CASE 7}

$H S$ is a 15 -year-old Caucasian girl with Noonan's syndrome and pulmonic stenosis. Although her bleeding time and PTT are normal, she has a serum defect in TGT summarized in Table 1. Her platelets fail to show secondary aggregation with ADP, norepinephrine, or thrombin but respond normally to collagen. She did not bleed excessively during or after open heart surgery.

\section{CASE 8}

$J M$ is a 12 -year-old black male with Noonan's syndrome and pulmonic stenosis. As with $H S$, his bleeding time and PTT are normal but a serum defect is present in the TGT with characteristics summarized in Table 1. Not even primary aggregation of platelets is seen with ADP, norepinephrine, collagen, or thrombin.

CASE 9

$M R$ is a 9-year-old girl with partial albinism and a history of easy bruising. Her bleeding time is $4 \mathrm{~min}$ and PTT is normal.
Her platelets respond normally to ADP and norepinephrine but poorly to collagen. The same serum defect in TGT was found.

\section{CASE 10}

$A M$ is a 5-year-old Caucasian girl with a history of severe bruising since infancy. Her bleeding time is greater than 15 min, requiring pressure dressing for hemostasis. Factor VIII assays are consistently normal. Her platelet factor 3 activity is normal but no aggregation occurs when ADP, collagen, norepinephrine, or thrombin is added to her PRP. Her thromboplastin generation test shows a serum defect with the same characteristics.

\section{CASE 11}

$M M$ is an 8-year-old Caucasian male from the same community and with the same surname as case 10 . The families are not aware of being related. His history is milder
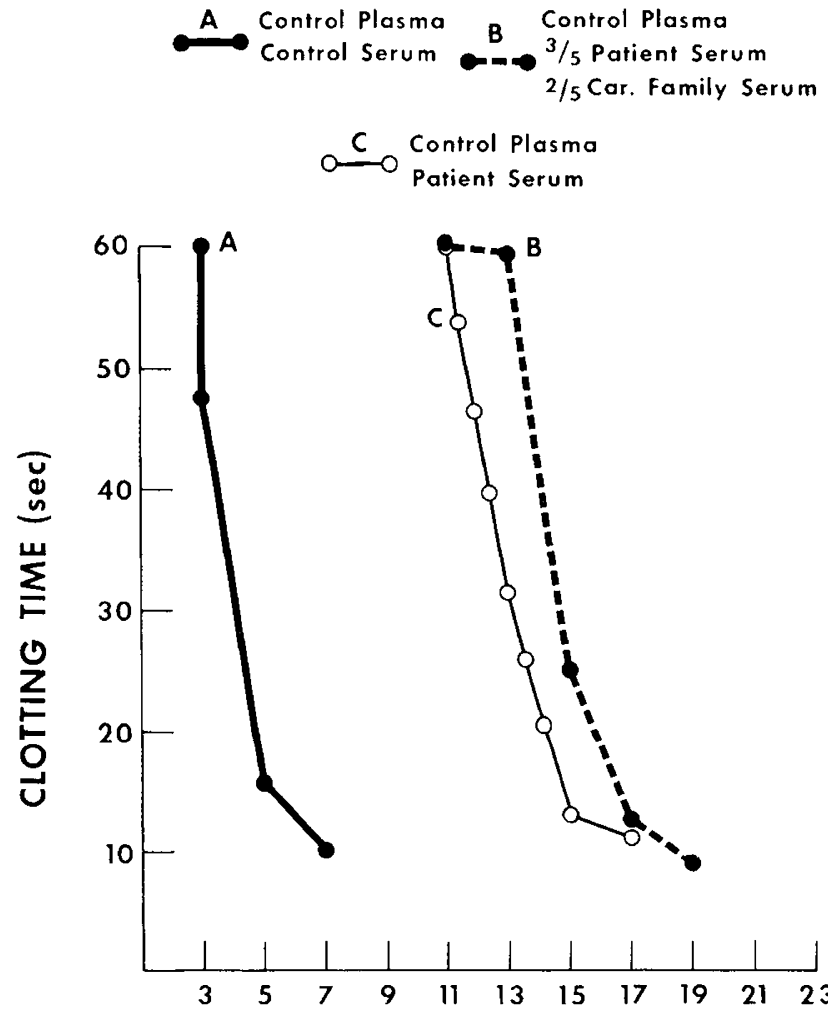

INCUBATION TIME (min)

Fig. 3. Thromboplast ry generation tests on patient $R K$ showing crossing studies with Car. family serum.

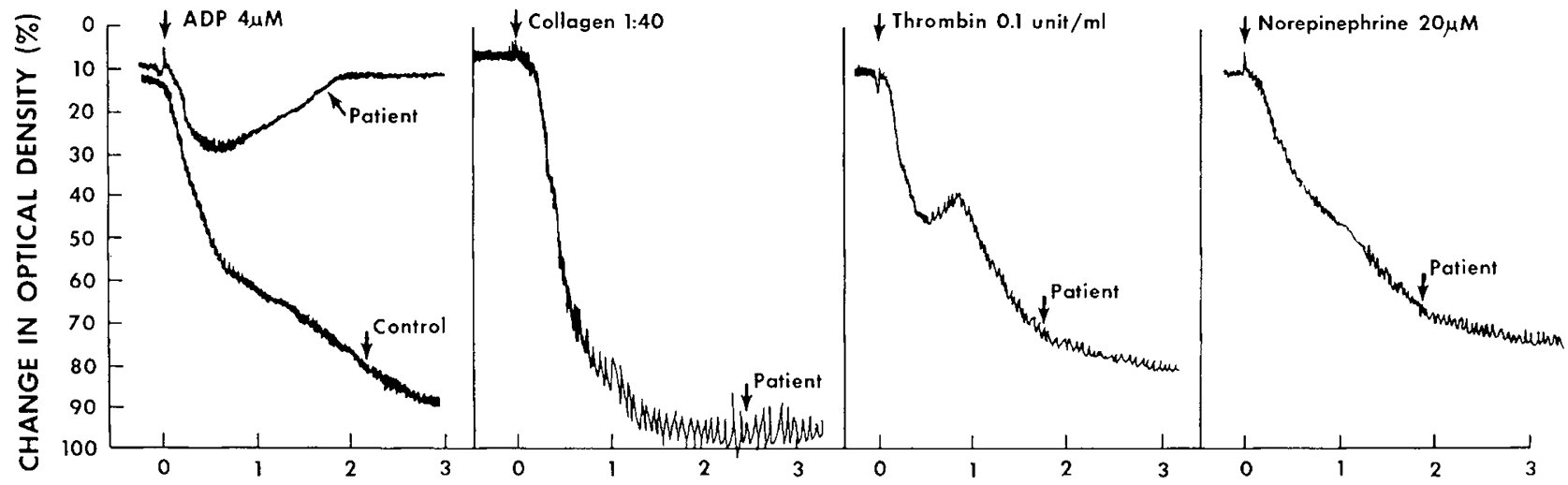

TIME IN MINUTES

Fig. 4. Platelet aggregation curves for patient $R K$. 
than $A M$ 's and his bleeding times have varied from $4 \mathrm{~min}$ to more than $15 \mathrm{~min}$ on different occasions. Factor VIII assays on $M M$ and his parents have been consistently within the normal range. Platelet aggregation to ADP, collagen, norepinephrine, and thrombin have been abnormal whether the bleeding time has been 4 or $15 \mathrm{~min}$. The serum defect was present on all occasions studied.

\section{CASE 12}

$L A$ is a 5 -year-old male with severe classic hemophilia $(<1 \%$ AHF). Family history includes documented classic hemophilia in maternal brothers and nephews. Both parents and three sisters are asymptomatic and have normal factor VIII levels and bleeding times. A bleeding time obtained on $L A$ at the time of initial diagnosis was normal. The TGT revealed typical plasma defect seen in classic hemophilia. Platelet aggregation to ADP, collagen, norepinephrine, and thrombin were normal.

During an episode of acute hemarthrosis, factor VIII concentrates were given and the AHF level assayed at $55 \%$ of normal. Because of pain, aspirin was administered. Eight hours later, the hemarthrosis was unimproved and nosebleeding began. AHF was assayed at $40 \%$ of normal; bleeding time was $>15$ min. Platelets showed impaired aggregation to ADP, collagen, norepinephrine, and thrombin. A TGT showed a serum defect only. Re-evaluation 2 weeks later showed a normal bleeding time, normal platelet aggregation, and no serum defect on TGT.

\section{CASES $13-22$}

Ten normal adult male volunteers were studied before and 2 $\mathrm{hr}$ after ingestion of 10 grains aspirin. The results are summarized in Table 1.

Table 1. Effect of aspirin on normal donors ${ }^{1}$

\begin{tabular}{|c|c|c|c|c|c|c|}
\hline \multirow[b]{2}{*}{ Case } & \multicolumn{2}{|c|}{$\begin{array}{l}\text { Bleeding time } \\
\min \end{array}$} & \multicolumn{2}{|c|}{$\begin{array}{c}\text { Platelet aggregation } \\
\text { to ADP, } \%\end{array}$} & \multicolumn{2}{|c|}{$\begin{array}{l}\text { TGT serum } \\
\text { defect }\end{array}$} \\
\hline & Before & After & Before & After & Before & After \\
\hline 13 & 2 & 6 & 80 & 20 & - & - \\
\hline 14 & 6 & 12 & 75 & 10 & - & + \\
\hline 15 & 3 & 6 & 90 & 15 & - & + \\
\hline 16 & $4^{1 / 2}$ & 6 & 70 & 70 & - & - \\
\hline 17 & $31 / 2$ & 5 & 85 & 80 & - & - \\
\hline 18 & $61 / 2$ & 9 & 70 & 10 & - & + \\
\hline 19 & 5 & 10 & 80 & 15 & - & + \\
\hline 20 & 7 & 13 & 75 & 20 & - & - \\
\hline 21 & $2^{1 / 2}$ & 6 & 80 & 75 & - & - \\
\hline 22 & 3 & 9 & 90 & 20 & - & + \\
\hline
\end{tabular}

${ }^{1}$ TGT: thromboplastin generation test.

\section{RESULTS}

\section{NORMAL COAGULATION STUDIES}

The following coagulation studies were normal in all affected members of the Virginia and Car. families: PT, PTT, platelet count, platelet morphology, fibrinogen, factors II, V, VII-X, XI, XII, Fletcher factor, prothrombin consumption, platelet factor 3, bleeding time, Rumple-Leed test, clot retraction, and platelet adhesiveness.

\section{THROMBOPLASTIN GENERATION CROSS-CORRECTION STUDIES}

All clinically affected members of both families had serum defects of the TGT when the "serum" was formed by the clotting of whole blood. Recalcification of citrated plasma with clot retraction by inosithin did not yield consistent results on the Virginia family (Table 2). Although a serum defect was occcasionally found this was, on other occasions, absent. "Serum" formed in this manner from three members of the Car. family gave normal results in the TGT.

The addition of $1 / 5$ normal serum by volume was adequate to correct the defect in both families. Addition of $1 / 5$ to $4 / 5$ volume serum from any of the three Car. family members did not correct $A B, G K$, or $R K$ (Fig. 3).

Addition of $1 / 5$ to $4 / 5$ volume $\mathrm{BaSO}_{4}$-absorbed serum did not correct any of the affected individuals, but all were corrected by prothrombin complex concentrate or Coumadin serum (Fig. 2)

Although the defect was present in serum incubated for only $1 \mathrm{hr}$ in contact with its clot, the defect was more marked in both the Car. and Virginia families after prolonged incubation (Fig. 5).

Inhibitory activity was not demonstrated for either "Car.deficient" serum or serum from affected members of the Virginia family. Incubation at $37^{\circ}$ of these sera with normal sera for periods up to an hour did not produce any abnormalities.

The addition of from 0.02 to 0.04 units of thrombin to the reaction mixture corrected the defect of both the Virginia and Car. families (Fig. 6). Addition of 0.04 units thrombin to a reaction mixture containing serum from a patient with less than $1 \%$ factor IX was not corrective.

Normal serum heated to $60^{\circ}$ for $3 \mathrm{~min}$ was not capable of correcting the defect of the Virginia or Car. families, but was itself corrected by the addition of 0.02 units thrombin.

\section{PLATELET AGGREGATION STUDIES IN VIRGINIA FAMILY}

Aggregation was normal in the asymptomatic members $(A K$, $T K$, and $R e K)$ to all agents added. In the affected members ( $G K, R K$, and $A B)$, aggregation to norepinephrine, collagen,

Table 2. Summary of cross-correction studies on reported serum defects ${ }^{1}$

\begin{tabular}{|c|c|c|c|c|c|c|c|}
\hline \multirow[b]{2}{*}{ Series } & \multirow[b]{2}{*}{ Thrombin } & \multirow[b]{2}{*}{ Heated serum } & \multicolumn{4}{|c|}{ Addition to patient's defective serum } & \multirow[b]{2}{*}{$\begin{array}{l}\text { Patient's } \\
\text { recalcifie } \\
\text { plasma }\end{array}$} \\
\hline & & & $\begin{array}{l}\text { Dilute } \\
\text { serum }\end{array}$ & $\begin{array}{c}\mathrm{BaSO}_{4}^{-} \\
\text {adsorbed } \\
\text { serum }\end{array}$ & $\begin{array}{l}\text { Car. } \\
\text { serum }\end{array}$ & $\begin{array}{c}\text { Coumadin } \\
\text { serum }\end{array}$ & \\
\hline Chirico (1957) Car. family & N.S. & $3 \min$ at $60^{\circ}$ & N.S. & - & N.S. & - & N.S. \\
\hline Connor (1961) labile serum factor & + & $5 \mathrm{~min}$ at $56^{\circ} \mathrm{C}$ & - & - & N.S. & - & N.S. \\
\hline Virginia family, $A B, R K, G K$ & + & $3 \mathrm{~min}$ at $60^{\circ}$ & - & - & - & + & \pm \\
\hline Noonan's syndrome, $H S, J M$ & + & $3 \min$ at $60^{\circ}$ & - & - & - & + & + \\
\hline Albinism, $M R$ & + & 3 min at $60^{\circ}$ & - & - & - & + & + \\
\hline Portsmouth syndrome, $A M$ & + & $3 \mathrm{~min}$ at $60^{\circ}$ & - & - & - & + & + \\
\hline
\end{tabular}

${ }^{1}$-: abnormal thromboplastin generation test (TGT); +: normal TGT; \pm : inconsistent results on repetition; N.S.: not specified or not done. 


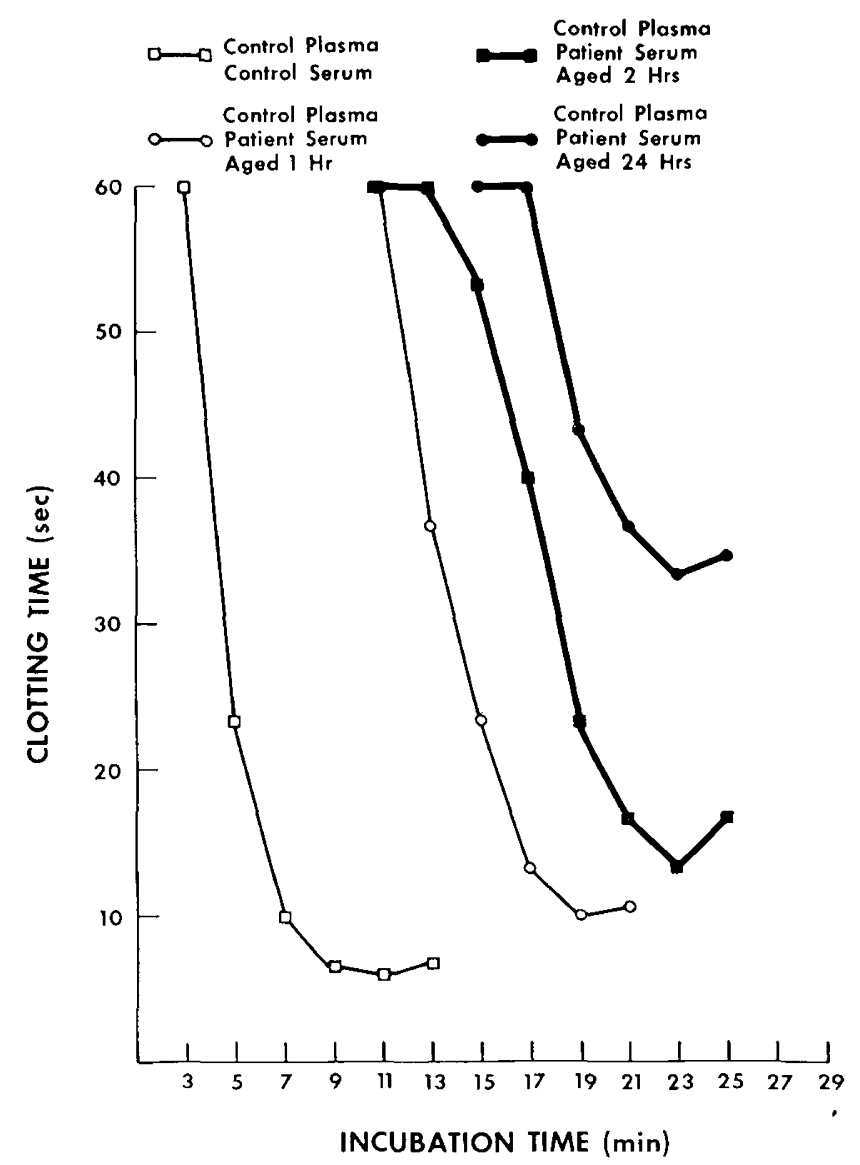

Fig. 5. Thromboplastin generation tests on patient $G K$ showing influence of length of time of serum formation.

and thrombin were normal. When $1-4 \mu \mathrm{M}$ ADP were used as the aggregating agent, there was no secondary wave of aggregation and disaggregation was rapid, even at $4 \mu \mathrm{M}$ ADP (Fig. 4).

\section{HEMOGLOBIN ELECTROPHORESIS}

All members of the Virginia family and Car. family have hemoglobin $A$ with normal levels of $A_{2}$ and $F$. None have hemolytic anemias or reticulocytosis.

\section{DISCUSSION}

The coagulation defect in all these patients is characterized by defective serum components in the TGT in the face of a normal PTT. The lack of cross-correction by Virginia and Car. sera suggest that the defective component is identical. The normal PTTs, loss of the defect when recalcified plasma is substituted for true serum, and failure of plasma transfusion to correct the TGT suggest that this is an artifact of serum preparation rather than deficiency of a new coagulation factor in the intrinsic pathway.

Serum defects in TGT have been described in association with hemoglobinopathies $(2,15)$, presumably from interaction of the abnormal red cell and the forming serum. These defects are more pronounced on prolonged incubation. Hemoglobin electrophoresis is normal in both families described.

In addition to the Car. factor and hemoglobinopathy patients, Connor et al. (9) reported a series of patients with "labile serum factor." Table 2 summarizes a comparison of the reported serum defects. Except for minor differences, it is likely that these reports probably involve the same defect. Both Henstell et al. (15) and Connor et al. (9) reported correction of the defect by the addition of dilute thrombin to the reaction mixture and failure of heated (thrombin-inacti-

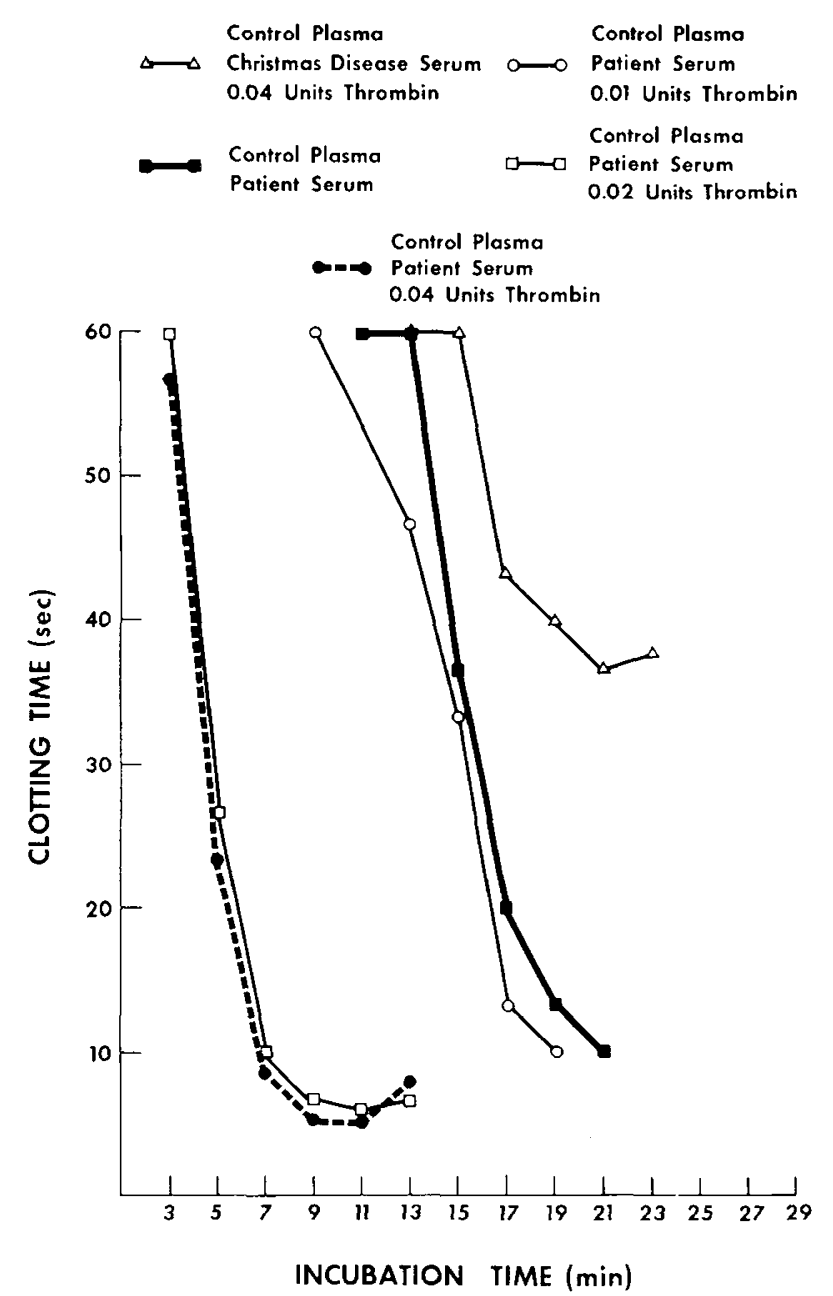

Fig. 6. Thromboplastin generation tests on patient $B P$ (Car. family) showing influence of dilute thrombin.

vated) serum to correct. These same features have been demonstrated in the Virginia patients and Car. family.

Platelet aggregation studies in the Virginia family revealed a qualitative platelet defect. Similar studies were not performed on the Car. family so that a platelet defect has not been confirmed. After our identification of the platelet defect in patients with "Car. defects," we restudied patients in whom we had previously identified either a nonspecific serum defect or platelet aggregation defect. Identification of concurrent platelet and TGT defects in these additional patients suggests that the Car. factor deficiency is a nonspecific defect. Rather than representing the deficiency of a plasma coagulation factor, it represents the removal of, or failure to generate thrombin in the presence of an abnormal cellular element of the blood, either red blood cell or platelet.

The platelet defect in the Virginia family bears some resemblance to the "platelet release defects" $(12,18)$; normal platelet factor 3, abnormal aggregation to exogenous ADP, and normal bleeding time in some individuals (17). In our series normal bleeding times in association with previously described qualitative platelet defects $(14,16)$ were seen with Noonan's syndrome and albinism. Although patients with significant clinical bleeding problems usually have prolonged bleeding times, this time-honored screening test may not be adequate to detect all cases of qualitative platelet dysfunction.

The presence of the same serum defect in TGTs of patients with a variety of qualitative platelet defects including aspirin-induced release defect emphasizes the nonspecificity of the serum defect that no longer merits the name of "Car. factor deficiency." 
SUMMARY

The previously described "Car. factor" deficiency appears to be a nonspecific removal of thrombin from serum during the interaction of abnormal cellular elements of the blood during clotting of whole blood in glass.

In the new cases described, bleeding time and PTT were inadequate to identify patients with significant bleeding problems. In patients with histories suggestive of a significant bleeding disorder but with normal screening studies, further testing may be required to clarify the problem.

\section{REFERENCES AND NOTES}

1. Abilgaard, C. F., Simone, J. V., Honig, G. R., Forman, E. N., Johnson, C. A., and Seeler, R. A.: von Willebrand's disease: A comparative study of diagnostic tests. J. Pediat., 73: 355 (1969).

2. Basu, A. K., Swarup, S., and Chatterjea, J. B.: Defective generation of thromboplastin in $\mathrm{Hbn} \mathrm{E}$-thalassemia and $\mathrm{Hbn} \mathrm{E}$ disease. Bull. Calc. School Trop. Med., 13: 121 (1965).

3. Biggs, R.: The thromboplastin generation test. J. Clin. Path., 6: 23 (1953)

4. Biggs, R. M., and Macfarlane, R. G.: Human Blood Coagulation, Ed. 3 (F. A. Davis Co., Philadelphia, 1962).

5. Born, G. V. R., and Cross, M. J.: The aggregation of blood platelets. J. Physiol., 168: 178 (1963).

6. Bouhasin, J. D., and Atlay, C.: Factor XIII deficiency: Concentrations in relatives of patients and in normal infants. J. Pediat., 72 . 336 (1968).

7. Brecher; G., and Cronkite, E. P.: Morphology and enumeration of human blood platelets. J. Appl. Physiol., 3: 365 (1950).

8. Chirico, A. M., and McElfresh, A. E.: A possible new thromboplastin deficiency occurring in five siblings. Blood, 12: 933 (1957).

9. Connor, W. E., Warner, E. D, and Carter, J. R.: A labile serum factor clotting defect: its demonstration by the thromboplastin generation test and its clinical significance. J. Clin. Invest., 40:13 (1961).

10. Hardisty, R. M., and Macpherson, J. C.: A one-stage factor VIII (antihemophilic globulin) assay and its use of venous and capillary plasma. Thromb. Diath. Haemorrh., 7: 215 (1962).

11. Hardisty, R. M., and Hutton, R. A.: Kaolin clotting time of platelet rich plasma; test of platelet factor 3 availability. Brit. J. Haematol., 11: 258 (1965).

12. Hardisty, R. M., and Hutton, R. A.: Bleeding tendency associated

Copyright (C) 1975 International Pediatric Research Foundations, Inc. with "new" abnormality of platelet behaviour. Lancet, $i: 983$ (1967).

13. Hathaway, W. E., and Hattersley, P. G.: Fletcher factor deficiency: Report of four additional unrelated cases and further coagulation studies. Blood, 34: 833 (1969).

14. Hathaway, W. E.: Bleeding disorders due to platelet dysfunction. Amer. J. Dis. Child., I21: 127 (1971).

15. Henstell, H. H., Klegerman, M., and Irwin, L. E.: Sickle cell disease A serum defect in the thromboplastin generation test. Blood, 25: 907 (1965).

16. Logan, L. J., Rapaport, S. I., and Maher, I.: Albinism and abnormal platelet function. N. Engl. J. Med., 284: 1340 (1971).

17. Maurer, H. M., Still, W. J. S., Caul, J., Valdes, O. S., and Laupus, W. E.: Familial bleeding tendency associated with microcytic platelets and impaired release of platelet adenosine diphosphate. J. Pediat., 78: 86 (1971).

18. O'Brien, J. R.: Platelets: a Portsmouth syndrome? Lancet, ii: 258 (1967).

19. Proctor, R R and Rapaport, S, I. The partial thromboplastin time with Kaolin. Amer. J. Clin. Path., 36: 212 (1967).

20. Quick, A. J.: Quantitative estimation of prothrombin. Amer. J. Clin. Path., 36: 212 (1967).

21. Ratnoff, O. D., and Menzie, C.: A new method for the determination of fibrinogen in small samples of plasma. J. Lab. Clin. Med., 37: 316 (1951).

22. Ratnoff, O. D., and Davis, E. W.: The purification of activated Hageman factor (activated factor XII). Biochemistry, $l: 967$ (1962).

23. Roberts, H. R., Frizzle, J. E., McLester, W. D., and Penick, G. D. Genetic variants of hemophilia B: Detection by means of a specific PTC inhibitor. J. Clin. Invest., 47: 360 (1968).

24. Salzman, E. W: Measurement of platelet adhesiveness. A simple in vitro technique demonstrating an abnormality in von Willebrand's disease. J. Lab. Clin. Med., 62: 724 (1963).

25. Sigma Chemical Co., St. Louis, Mo.

26. Lerophed, Winthrop Laboratories,

27. Parke-Davis,

28. Amphojel, Wyeth Laboratories,

29. Konyne, Cutter Laboratories,

30. Dr. Anna Marie Chirico arranged contact with the original "Car." family

31. All blood studies and transfusions were performed on Virginia patients in association with diagnostic and therapeutic tests to support required surgery and deemed necessary for treatment. The original "Car. family" consented to donate their blood to clarify the nature of the problem in the Virginia family.

32. Requests for reprints should be addressed to: D. M. Komp, M.D. University of Virginia School of Medicine, Department of Pediatrics, Charlottesville, Virginia 22901 (USA).

33. Accepted for publication January 2, 1975 . 